\title{
Transfer of Learning: The Missing Ingredient
}

\author{
Bassem Kandil ${ }^{1, *}$ \\ ${ }^{1}$ Saint Joseph University of Beirut, Lebanon \\ *Corresponding author: Saint Joseph University of Beirut, Lebanon. E-mail: \\ Bassem.kandil1@usj.edu.lb
}

Received: May 23, 2021 Accepted: June 21, 2021 Published: August 17, 2021

doi:10.5296/ije.v13i3.18668ＵRL: https://doi.org/10.5296/ije.v13i3.18668

\begin{abstract}
The achievement scores of the Lebanese students that participated in the international exams such as TIMSS and PISA are unsatisfactory and they are not getting better with time. As a matter of fact, this is the case for many countries in the MENA region. In order to address this challenge, a precursor is to identify the main root causes for such a performance. For this purpose, this study aimed at examining whether a sample of Grade 8 students are able to demonstrate transfer of learning in the context of math and science. The findings showed that the examined students couldn't answer the questions that require conceptual understanding or higher-order thinking; thus they couldn't practice transfer of learning. An implication for this study is that transfer of learning is not something that happens by coincidence nor it's something that can be overlooked.
\end{abstract}

Keywords: transfer of learning, students' achievement, TIMSS 


\section{Introduction}

TIMSS, Trends in International Mathematics and Science Study, is an international assessment of mathematics and science at the fourth and eighth grade levels which takes place every four years. The importance of such an examination emanates from the fact that it generates valuable trend data for monitoring the effectiveness of the respective educational systems in various countries. In order to correctly answer TIMSS test items, students need to be familiar with the mathematics and science content being assessed, and they need to draw on a range of cognitive skills that belong to the following three cognitive domains: Knowing, Applying, and Reasoning. The mathematics content domains for Grade 8 are: Number, Algebra, Geometry, and Data and Probability. As for the science content domains, they are: Biology, Chemistry, Physics, and Earth Science (Mullis \& Martin, 2017).

The three cognitive domains are the same for mathematics and science. "The first domain, knowing, covers the facts, concepts, and procedures students need to know; the second domain, applying, focuses on the ability of students to apply knowledge and conceptual understanding to solve problems or answer questions; and the third domain, reasoning, goes beyond the solution of routine problems to encompass unfamiliar situations, complex contexts, and multistep problems". "It is important to emphasize that the items in each TIMSS assessment cover a range of thinking skills, including students' abilities to apply what they have learned, solve problems, and use analysis and logical thinking to reason through situations; two-thirds of the items require students to use applying and reasoning skills" (Mullis \& Martin, 2017).

Since 2003, many things have changed except the poor performance of Lebanon in the TIMSS exams. The achievement trend displayed below clearly show that Lebanon consistently scored below the TIMSS scale Centerpoint (500), below many other participating countries, and what is even worse is that the performance of its participating students is not getting better with time.

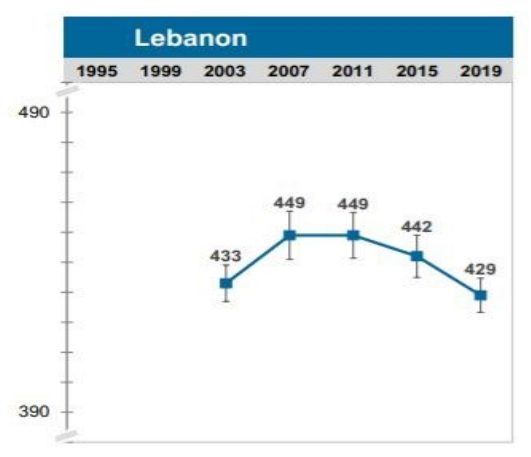

Figure 1. Achievement Trend in TIMSS-Mathematics 


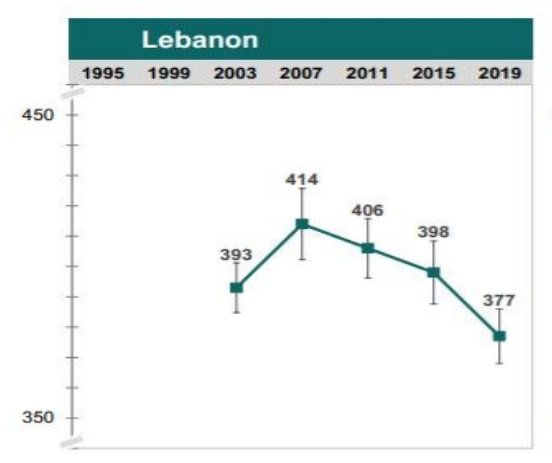

Figure 2. Achievement Trend in TIMSS-Science

Among the various factors that might be the cause of such a poor performance in TIMSS exams is the lack of transfer. Thus, this study aims at exploring a significant factor, transfer of learning, which directly affects achievement and problem solving; especially in math and science. According to Haskell (2001), "the more skilled we are in transfer, the more creative and efficient is our thinking and performance" (p. 24).

A significant aspect that is related to the performance of Grade 8 Lebanese students in the TIMSS exams is their ability to solve similar problems or to address similar challenges in their respective local schools. That's why identifying the type of learning that is taking place in the respective classrooms is a precursor towards resolving the achievement issue in any external examination such as TIMSS. Thus, the results of this study will pave the way towards the development of successful remedial routines or relevant reform efforts in the future.

The international standardized exams such as TIMSS consists mainly of questions that require deep conceptual understanding or higher-order thinking in order to correctly answer them; thus the aim of this study is to examine whether Grade 8 students who participated in TIMSS 2015 and TIMSS 2019 were able to solve problems that require conceptual understanding or higher-order thinking like applying or reasoning. In addition, the current research aims at exploring whether a sample of eighth graders, in a selected private school, are able to transfer their learning in math and science to other situations that require deep conceptual understanding or higher-order thinking. In particular, this study was guided by the following research questions:

(a) What are the types of questions that Grade 8 Lebanese students failed to answer correctly in the recent TIMSS exams? (b) Is learning transferable in the eighth grade science and math classrooms in a private school in Beirut-Lebanon?

\section{Theoretical Framework}

The theoretical framework of this study is underpinned by the Situated Learning Theory. Leaning and cognition are developed when students are actively involved in purposeful 
authentic activities (Lave \& Wenger, 1991). Mestre (2002) defined transfer as: "the ability to apply knowledge or procedures learned in one context to new context" (p.3). Marini and Genereux (1995) defined transfer of learning as: "prior knowledge affecting new learning or performance" (p.2). Transferring knowledge from one situation or context to a similar situation, or near transfer, is relatively easy, while transferring knowledge to novel situations, or far transfer, is more challenging (Bransford, et al., 1999). Many students find transfer of learning to situations other than the one in which it was learned a challenging task (Gilbert \& Hayes, 1996).That's why, schools should aim for transfer among the various subject matters and from classrooms to other aspects of a student's life (Shelley \& Yildrim, 2013). In addition, transfer of learning doesn't come spontaneously or by coincidence; educators need to aim for transfer, plan for transfer, teach for transfer and assess accordingly.

\section{Method}

This study is a descriptive case study that consists of collecting and analyzing data from two different sources. Through analyzing the collected data, the researcher aims to discover whether the sampled students are able to transfer their learning in Mathematics and Science to other situations. The first source of data is the examination and the analysis of the TIMSS scores of the Grade 8 Lebanese students over an extended period of time. According to the Center for Educational Research and Development (2018), 3873 grade eight students from 138 schools participated in TIMSS 2015. Students were randomly selected from the private $(65 \%)$ and public $(35 \%)$ sectors.

The second source of data is extracted from a performance-based activity that requires transfer of learning which was implemented in a selected Grade 8 classroom. This activity was followed by an evaluation sheet to assess the conceptual understanding of the topics covered in the activity; along with a discussion session with the students and teachers. Forty five Grade 8 students who belong to two sections (A and B) and are enrolled in a private school that is located in Beirut constituted the sample or the participants of this part of the study. Twenty four students in section A, and 21 students in section B.

\section{Results and Discussion}

\subsection{TIMSS-Mathematics}

In mathematics, Lebanon consistently scored below the TIMSS scale Centerpoint (500) and its performance was below most of the countries that participated in the corresponding TIMSS exams. In addition, the performance of its participants didn't get any better with time as shown in Table 1. 
Table 1. TIMSS-Mathematics Achievement for Grade 8 Lebanese Participants

\begin{tabular}{cc}
\hline Year & TIMSS - Mathematics \\
\hline 2003 & 433 \\
2007 & 449 \\
2011 & 449 \\
2015 & 442 \\
2019 & 429 \\
\hline
\end{tabular}

\subsubsection{Performance at International Benchmarks-Mathematics}

TIMSS identified four points along the achievement scale to serve as international benchmarks. These benchmarks are then used to describe what students can do and can't do in mathematics. Table 2 presents the percentage of Grade 8 Lebanese students, in comparison with others, who reached the various benchmarks. It is worth mentioning that the percentages illustrated in the Table 2 below are cumulative because students who reached the Advanced level are assumed to have reached the other levels. Concerning Lebanon, none of the Grade 8 Lebanese participants managed to get a mathematics score of 625 or above; very few students achieved scores at the High or Intermediate benchmarks. And these percentages are far below the international mean of scores of the respective benchmarks (Mullis, et al., 2020).

Table 2. Percentage of Students Reaching International Benchmarks of Mathematics (TIMSS)

\begin{tabular}{|c|c|c|c|c|c|c|}
\hline Benchmark & Score & Description & $\begin{array}{l}\% \text { of Grade } \\
8 \text { students } \\
\text { reaching } \\
\text { International } \\
\text { Benchmarks } \\
\quad(2015)\end{array}$ & $\begin{array}{l}\text { \% of Grade } \\
8 \text { Lebanese } \\
\text { students } \\
\text { reaching } \\
\text { International } \\
\text { Benchmarks } \\
(2015)\end{array}$ & $\begin{array}{c}\% \text { of Grade } \\
8 \text { students } \\
\text { reaching } \\
\text { International } \\
\text { Benchmarks } \\
\quad(2019)\end{array}$ & $\begin{array}{c}\% \text { of Grade } \\
8 \text { Lebanese } \\
\text { students } \\
\text { reaching } \\
\text { International } \\
\text { Benchmarks } \\
\text { (2019) }\end{array}$ \\
\hline Advanced & 625 & $\begin{array}{l}\text { Students can apply and } \\
\text { reason in a variety of } \\
\text { problem situations, solve } \\
\text { linear equations, and } \\
\text { make generalizations. }\end{array}$ & $5 \%$ & $0 \%$ & $5 \%$ & $0 \%$ \\
\hline High & 550 & $\begin{array}{l}\text { Students can apply their } \\
\text { understanding and } \\
\text { knowledge in a variety of } \\
\text { relatively complex } \\
\text { situations. }\end{array}$ & $26 \%$ & $8 \%$ & $25 \%$ & $5 \%$ \\
\hline Intermediate & 475 & $\begin{array}{l}\text { Students can apply basic } \\
\text { mathematical knowledge } \\
\text { in a variety of situations. }\end{array}$ & $62 \%$ & $35 \%$ & $56 \%$ & $27 \%$ \\
\hline Low & 400 & $\begin{array}{l}\text { Students have some } \\
\text { knowledge of whole } \\
\text { numbers and basic } \\
\text { graphs. }\end{array}$ & $84 \%$ & $71 \%$ & $87 \%$ & $64 \%$ \\
\hline
\end{tabular}




\subsubsection{Achievement by Cognitive Domains}

Figure 3 below displays the average mathematics achievement in the three domains (Knowing, Applying, and Reasoning) for Grade 8 Lebanese students. The scores show that the participating Lebanese students have a relative strength in the Knowing domain than they have in the Applying and Reasoning domains. Concerning the changes in performance between 2015 and 2019, there is significant decrease in the overall score as well as a decrease in the Applying cognitive domain (Mullis, et al., 2020).

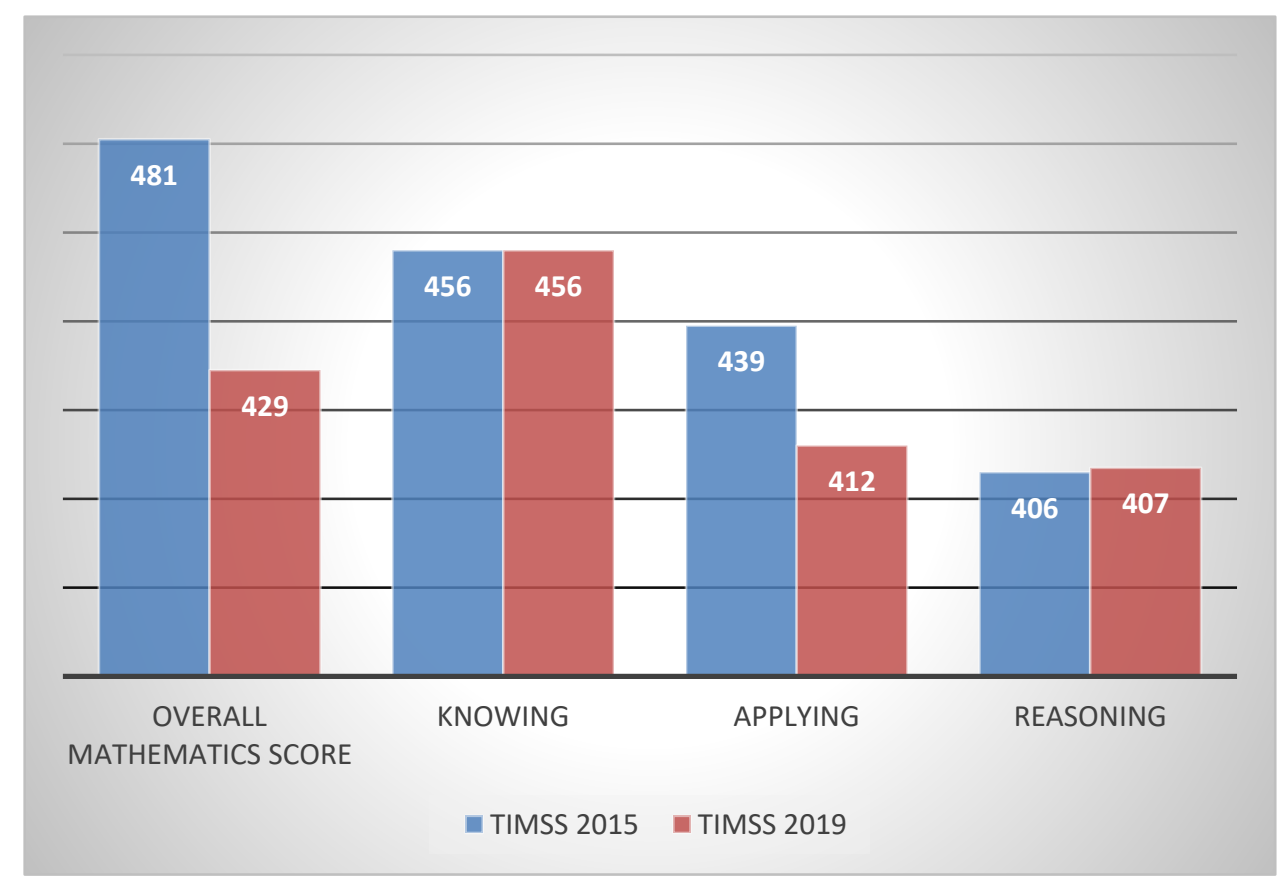

Figure 3. TIMSS Mathematics Scores for Grade 8 Lebanese Students

\subsection{TIMSS-Science}

In Sciences, Lebanon scored below the TIMSS scale Centerpoint (500) and its performance was below most of the countries that participated in the corresponding TIMSS exams. In addition, the performance of its participants didn't get any better with time as shown in Table 3.

Table 3. TIMSS-Science Achievement for Grade 8 Lebanese Participants

\begin{tabular}{cc}
\hline Year & TIMSS - Science \\
\hline 2003 & 393 \\
2007 & 414 \\
2011 & 406 \\
2015 & 398 \\
2019 & 377 \\
\hline
\end{tabular}




\subsubsection{Performance at International Benchmarks-Science}

Concerning Lebanon, only $1 \%$ of the Grade 8 Lebanese participants managed to get an overall score of 625 or above in Science; very few students achieved scores at the High or Intermediate benchmarks. And these percentages were far below the international mean of the scores of the respective benchmarks as shown in Table 4 below (Mullis, et al., 2020).

Table 4. Percentage of Students Reaching International Benchmarks of Science (TIMSS)

\begin{tabular}{|c|c|c|c|c|c|c|}
\hline Benchmark & Score & Description & $\begin{array}{l}\% \text { of Grade } \\
8 \text { students } \\
\text { reaching } \\
\text { International } \\
\text { Benchmarks } \\
\quad(2015)\end{array}$ & $\begin{array}{l}\% \text { of Grade } \\
8 \text { Lebanese } \\
\text { students } \\
\text { reaching } \\
\text { International } \\
\text { Benchmarks } \\
\quad(2015) \\
\end{array}$ & $\begin{array}{l}\% \text { of Grade } \\
8 \text { students } \\
\text { reaching } \\
\text { International } \\
\text { Benchmarks } \\
\quad(2019)\end{array}$ & $\begin{array}{l}\% \text { of Grade } \\
8 \text { Lebanese } \\
\text { students } \\
\text { reaching } \\
\text { International } \\
\text { Benchmarks } \\
\quad(2019) \\
\end{array}$ \\
\hline Advanced & 625 & $\begin{array}{l}\text { Students communicate } \\
\text { understanding of complex } \\
\text { concepts related to biology, } \\
\text { chemistry, physics and Earth } \\
\text { science in practical, } \\
\text { abstract, and experimental } \\
\text { contexts. }\end{array}$ & $7 \%$ & $1 \%$ & $7 \%$ & $1 \%$ \\
\hline High & 550 & $\begin{array}{l}\text { Students apply and } \\
\text { communicate understanding } \\
\text { of concepts from biology, } \\
\text { chemistry, physics, and } \\
\text { Earth science in everyday } \\
\text { and abstract situations. }\end{array}$ & $29 \%$ & $7 \%$ & $29 \%$ & $5 \%$ \\
\hline $\begin{array}{l}\text { Intermediat } \\
\mathrm{e}\end{array}$ & 475 & $\begin{array}{l}\text { Students demonstrate and } \\
\text { apply their knowledge of } \\
\text { biology, chemistry, physics, } \\
\text { and Earth science in various } \\
\text { contexts. }\end{array}$ & $64 \%$ & $24 \%$ & $61 \%$ & $19 \%$ \\
\hline Low & 400 & $\begin{array}{l}\text { Students show some basic } \\
\text { knowledge of biology, } \\
\text { chemistry, physics, and } \\
\text { Earth science. }\end{array}$ & $84 \%$ & $50 \%$ & $85 \%$ & $41 \%$ \\
\hline
\end{tabular}

\subsubsection{Achievement by Cognitive Domains}

Figure 4 below presents the average science achievement in the three domains (Knowing, Applying, and Reasoning) for Grade 8 Lebanese students. Similar to their achievement in mathematics, the scores show that Grade 8 Lebanese students have a relative strength in the Knowing domain than they have in the Applying and Reasoning domains. Concerning the last two performances (2015 and 2019), there is a decrease in the overall score as well as a decrease in all cognitive domains; especially the Applying and Reasoning ones (Mullis, et al., 
2020).

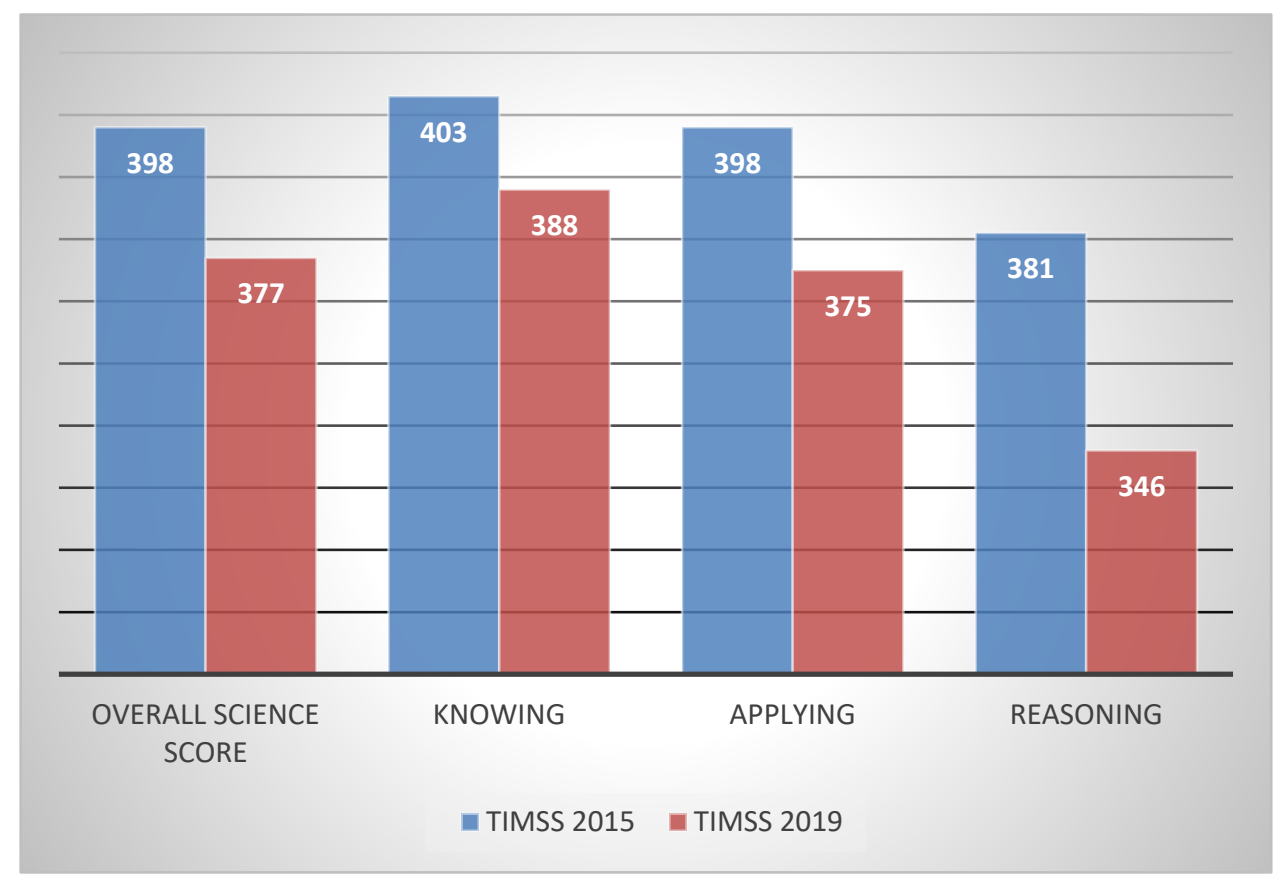

Figure 4. TIMSS Science Scores for Grade 8 Lebanese Students

\subsection{The Performance-based Activity}

Twenty four Grade 8 students that are enrolled in section A of the selected private school were asked to build a balloon-powered car as per certain detailed instructions that were given to them along with the required materials. Once done with building the car, students were asked to try the functionality of their corresponding cars. After that, students were asked to try their cars and record the distance covered by their respective cars, the time, the velocity and the number of wheel rotations traveled by their corresponding cars. Students managed to record what's required except for the calculation of the wheel rotations of their cars. They couldn't figure it out. Then, students were given an evaluation sheet to answer. The distributed sheet included questions about the conceptual understanding of the topics or concepts covered by the activity. Those topics and concepts were also supposed to be covered during their formal education or instruction in the current or previous academic years. The summary of their responses to the assigned questions can be found in Table 5 below: 
Table 5. The Percentages of Answers to the Evaluation Sheet

\begin{tabular}{lccc}
\hline \multicolumn{1}{c}{ Questions } & $\begin{array}{c}\text { Correct Answer } \\
\text { Total number of } \\
\text { students =24 }\end{array}$ & $\begin{array}{c}\text { Wrong Answer } \\
\text { Total number of } \\
\text { students }=24\end{array}$ & $\begin{array}{c}\text { No Answer } \\
\text { Total number of } \\
\text { students = 24 }\end{array}$ \\
\hline $\begin{array}{l}\text { Explain how did you calculate the number of } \\
\text { wheel rotations traveled by the moving car? }\end{array}$ & 0 & 0 & 24 \\
$\begin{array}{l}\text { Does the number of wheel rotations change if } \\
\text { we replaced the wheels by larger ones? In what } \\
\text { direction the change will be? }\end{array}$ & 8 & 10 & 6 \\
$\begin{array}{l}\text { If the car doesn't move in a straight line (drifts } \\
\text { off to one side), then the reason for this could } \\
\text { be? }\end{array}$ & 5 & 3 & 16 \\
$\begin{array}{l}\text { If the car doesn't move forward smoothly, then } \\
\text { the reason for this could be? }\end{array}$ & 7 & 4 & 18 \\
$\begin{array}{l}\text { What makes the car move? Explain your } \\
\text { reasoning in terms of Newton's law(s) and the } \\
\text { flow of energy? }\end{array}$ & 2 & 4 & 5 \\
$\begin{array}{l}\text { What type of energy does the car have when } \\
\text { the car is coasting after the balloon is } \\
\text { completely deflated? }\end{array}$ & 10 & 9 & \\
\hline
\end{tabular}

Then, and upon the examination of the submitted sheets, the researcher initiated a discussion session with the students; generating the following dialogue:

R: I noticed that most of you, if not all of you, couldn't answer the questions related to the wheel rotations. Let us try to work this out, together. If we perceive the wheel of the car as a circle, what concept may represent a single wheel rotation?

The provided hint didn't ring a bell to the students! So, another hint was given by the researcher through the following series of questions:

R: What if we know the circumference or the area of a circle? Does this help us calculate the rotations of the wheel (of the various cars)?

Again, the researcher didn't get satisfactory responses. One can infer that the examined students lack the conceptual understanding of a circumference.

$R$ : The researcher briefly explained the circumference of the circle and how it represents a single wheel rotation. Through its formula $(2 \pi r)$, students calculated the single rotation of the wheel. It's worth mentioning that, while calculating the circumference, some students paused for a while wondering how to get the value of $r$ ?

Then the discussion shifted to the other questions. Again, the responses or the non-responses of the students clearly revealed that the examined students suffered from lack of conceptual 
understanding regarding the concepts of Symmetry, Potential Energy, Kinetic Energy, and Newton's Laws of motion. Such a lack hindered their ability to correctly answer the required questions or solve problems related to those topics; especially those that require deep understanding or higher-order thinking.

In order to verify the findings, the researcher repeated the same activity along with the questions and the discussion session with the other class section, Section B, of the eighth grade level in the selected school. The performance, as well as the responses, were quite similar to those collected from Section A. Students lack the conceptual understanding of the relevant topics.

In addition, the respective math and science teachers where then asked to explain why the sampled Grade 8 students failed to provide scientific responses to the presented questions. They replied that "our students are not prepared for such types of questions or problems". And when the researcher asked them about the reason for that? They responded that "such performance-based activities or word problems that are contextualized in real-life situations are time consuming to plan and implement and that we are on a very tight schedule to cover the assigned curriculum". This means that students didn't have the opportunity to properly practice the acquired knowledge and skills...

Back to the first source of data, the relevant TIMSS data clearly show that Grade 8 Lebanese students couldn't transfer their learning in math and science to other situations. In particular, their overall performances in both subject matters are below the international CenterPoint (500) and they are also below the performances of most participating countries. What is even worse is that their performance in TIMSS is not getting any better with time; this is an indicator of a systemic problem in the Lebanese education system. In addition, the descriptions illustrated in the Table 2 and Table 4 above, stated that Grade 8 Lebanese students couldn't "apply or reason in a variety of problem situations" (Mullis, et al., 2020).

Concerning the second source of data for this study, the performance-based activity, the sampled Grade 8 students also couldn't answer the questions that require conceptual understanding and thus couldn't transfer learning in math and science to other contexts or situations. These findings are in accordance with the findings from the analysis of the relevant TIMSS data.

Both sources of data revealed absence of conceptual understanding along with lack of transfer. Transfer is not considered to occur if students are able to solve end-of-chapter problems; but not able to solve similar problems in other contexts or in real-life contexts (Shelley \& Yildrim, 2013). In addition, teaching for transfer or identifying transfer goals is an essential step in the first stage of the backward design. According to Wiggins and McTighe (2005), among the primary goals of the Understanding by Design (UbD) model are deep understanding and transfer of learning.

The consistency of such a poor performance of Grade 8 Lebanese students in the TIMSS exams or the prevailing lack of transfer reflects a systemic issue. According to Senge (2006), "When placed in the same system, people, however different, tend to produce similar results" 
(p. 42).

\section{Conclusion and Recommendation}

Teaching for transfer is a deliberate act (Lave \& Wenger, 1991). If students lack conceptual understanding or are not able to answer questions or tackle problems that require higher-order thinking then they will not be able to transfer their learning to other situations. TIMSS exams are no exception. In addition, if they can't transfer, then one might claim that they didn't learn what they were supposed to learn because the ultimate aim of education is to apply what has been learned in various contexts, and to extend that learning to new situations (Haskell, 2001). If educators want to improve the performance of the Lebanese students participating in the TIMSS, many things could be done. For instance, educators need to diversify the thinking levels of their activities and they should as well make an explicit connection between what's being learned and real life situations. In addition, students need to have the time and the opportunity to practice and reflect upon what's being learned. Educators, curriculum designers, and policy makers need to identify the systemic structures that are causing such an undesirable performance and then they should identify the high-leverage changes in the education system (Senge, 2006). Nevertheless, teaching for transfer remains a cornerstone in any reform. As for the breadth and depth of such a proposed reform, this may be a suitable topic for a new research study about how to teach for transfer?

\section{References}

Bransford, J., Brown, A., \& Cocking, R. (Eds.) (1999). How people learn: Brain, mind, experience, and school. Washington, DC: National Research Council.

Center for Educational Research and Development (2018). TIMSS 2015-Grade 8 National Report. Retrieved from https://www.crdp.org/project-details1/632/288

Gilbert, M., \& Cordey-Hayes, M. (1996). Understanding the process of knowledge transfer to achieve successful technological innovation. Technovation, 16(6), 301-312. https://doi.org/10.1016/0166-4972(96)00012-0

Lave, J., \& Wenger, E. (1991). Situated learning: Legitimate peripheral participation. Cambridge University Press. https://doi.org/10.1017/CBO9780511815355

Marini, A., \& Genereux, R. (1995). In Teaching for Transfer: Fostering Generalization inLearning. In McKeough, A., Lupart, J. and Marini, A. (Eds.), Lawrence Erlbaum Associates, Mahwah, NJ, 1-20.

Mestre, J. (2002). Transfer of learning: Issues and research agenda. National Science Foundation Reports. Retrieved from https://www.nsf.gov/pubs/2003/nsf03212/nsf03212.pdf

Mullis, I. V. S., \& Martin, M. O. (Eds.). (2017). TIMSS 2019 Assessment Frameworks. 
Retrieved from Boston College, TIMSS \& PIRLS International Study Center website. Retrieved from http://timssandpirls.bc.edu/timss2019/frameworks/

Mullis, I. V. S., Martin, M. O., Foy, P., Kelly, D. L., \& Fishbein, B. (2020). TIMSS 2019 International Results in Mathematics and Science. Retrieved from Boston College, TIMSS \& PIRLS International Study Center website. Retrieved from https://timssandpirls.bc.edu/timss2019/international-results/

Senge, P. M. (2006). The Fifth Discipline: The Art and Practice of the Learning Organization (Revised and Updated Edition). Random House.

Shelley, M., \& Yildirim, A. (2013). Transfer of learning in mathematics, science, and reading among students in Turkey: A study using 2009 PISA data. International Journal of Education in Mathematics, Science and Technology, 1(2), 83-95

Wiggins, G., \& McTighe, J. (2005). Understanding by Design (2nd ed.). Association for Supervision and Curriculum Development.

\section{Copyright Disclaimer}

Copyright for this article is retained by the author(s), with first publication rights granted to the journal.

This is an open-access article distributed under the terms and conditions of the Creative Commons Attribution license (http://creativecommons.org/licenses/by/3.0/). 